\title{
Numerical analysis of piston ring pack operation
}

\begin{abstract}
In the paper a model of a piston ring pack motion on an oil film has been analysed. The local oil film thickness can be compared to height of the combined roughness of mating surfaces of piston rings and cylinder liner. Equations describing the mixed lubrication problem based on the empirical mathematical model formulated in works of Patir, Cheng [6, 7] and Greenwood, Tripp [3] have been combined [12] and used in this paper. A model of a gas flow through the labyrinth seal of piston rings has been developed [13, 15]. In addition models of ring twist effects and axial ring motion in piston grooves have been applied $[14,15]$.

In contrast to the previous papers of the author, an experimental verification of the main parts of developed mathematical model and software has been presented. A relatively good compatibility between the experimental measurements and calculated results has been achieved. In addition this study presents the simulation results for an automobile internal combustion engine.
\end{abstract}

Key words: piston rings, gas dynamics, hydrodynamics, surface roughness

\section{Analiza numeryczna funkcjonowania pakietu pierścieni tlokowych}

W artykule przedstawiono kompleksowy model ruchu pakietu pierścieni tłokowych po filmie olejowym o grubości porównywalnej z sumaryczna chropowatościa powierzchni roboczych pierścieni tłokowych i tulei cylindrowej. Zaadaptowano model przepływu oleju w szczelinie o chropowatych ściankach Patira i Chenga [6, 7] oraz model elastycznego kontaktu chropowatych powierzchni Greenwooda i Trippa [3]. Opracowano także model przepływu gazu przez uszczelnienie labiryntowe pierścieni [13, 15] oraz model odkształceń kątowych pierścieni i ich pionowych przeskoków w rowkach ttoka $[14,15]$.

W odróżnieniu od poprzednich artykułów autora, w niniejszym przedstawiono eksperymentalna weryfikację głównych członów opracowanego kompleksowego modelu matematycznego oraz oprogramowania. Uzyskano relatywnie dobra zgodność ilościowa i jakościowa wyników obliczeń symulacyjnych i badań eksperymentalnych. Ponadto przedstawiono wyniki obliczeń symulacyjnych dla samochodowego silnika spalinowego.

Słowa kluczowe: pierścienie tłokowe, dynamika gazów, hydrodynamika, chropowatość powierzchni

\section{Introduction}

Piston rings are important part of internal combustion engines. Commonly a set of piston rings is used to form a dynamic gas seal between the piston and cylinder wall. The sliding motion of the piston forms a thin oil film between the ring land and cylinder wall, which lubricates the sliding components $[4,9,11]$. The hydrodynamic force generated by this thin oil film is opposed by a combination of the gas pressure acting on the back side of each ring and the ring stiffness. Due to the dynamic nature of these forces, each individual ring is periodically compressed and extended as the piston runs through its cycle. The problem of studying this interaction is further complicated by the high temperatures involved, as these result in low oil viscosity and subsequently very low oil film thickness. The oil film is typically thick enough to expect the existence of mixed lubrication, so this phenomenon should also be taken into account $[1,3,6$, $7,12]$. Numerical simulation of these processes, which take place in a typical piston ring pack operation, is important from practical point of view.

The purpose of this paper is to present an experimental verification of the main parts of developed mathematical model and also chosen numerical calculations of piston ring pack operation for an automobile internal combustion engine.

\section{Wstęp}

Pierścienie tłokowe stanowią istotną część silników spalinowych. Zwykle stosowany jest zestaw pierścieni tłokowych, aby utworzyć dynamiczne uszczelnienie gazowe pomiędzy tłokiem i gładzią cylindrową. Ruch ślizgowy tłoka przyczynia się do powstania cienkiej warstewki oleju pomiędzy wargą pierścienia i powierzchnią cylindra, która smaruje elementy ślizgowe $[4,9,11]$. Siła hydrodynamiczna powstająca w tym cienkim filmie olejowym przeciwdziała złożeniu siły ciśnienia gazu działającego na wewnętrzne strony każdego pierścienia i siły sprężystości pierścienia. Z uwagi na dynamiczny charakter tych sił, każdy pierścień z osobna jest okresowo sprężany i rozprężany, gdy tłok przemieszcza się $\mathrm{w}$ ramach cyklu pracy silnika. Zagadnienie analizy tych oddziaływań jest dodatkowo skomplikowane przy wysokich temperaturach, gdyż wtedy prowadzi to do obniżenia lepkości oleju i w konsekwencji do bardzo cienkich warstewek oleju. Zwykle jednak film olejowy ma wystarczającą grubość do istnienia tarcia mieszanego. Zatem to zjawisko powinno być także uwzględniane w analizie $[1,3,6,7,12]$. Symulacja numeryczna procesów, które towarzyszą pracy typowego pakietu pierścieni tłokowych, jest istotna $\mathrm{z}$ praktycznego punktu widzenia.

Celem tego artykułu jest przedstawienie eksperymentalnej weryfikacji głównych elementów opracowanego modelu 


\section{Modelling of piston ring pack operation}

\subsection{Developed sub-models}

A combined model of piston rings operation has been developed. It consists of two main models: a) model of gas flow through the labyrinth seal piston-rings-cylinder, b) model of oil flow in the lubrication gap between the ring and cylinder liner. The both mentioned models are coupled. In addition sub-models of the following mechanical phenomena have been used: a contact of rough surfaces, an axial movement of rings within piston grooves and an elastic torsional deformation of piston rings.

\subsection{Model of gas flow through the labyrinth seal of piston rings}

The gas flow model $[13,15]$ consists of several volume regions $(\mathrm{V} 1, \mathrm{~V} 2, \ldots, \mathrm{V} 5)$, which are connected by orifices with cross-section areas A1, A2, .., A6 (Fig. 1). The volumes V3, V5 correspond to volumes of among the piston rings, while volumes V2, V4 correspond to groove volumes behind rings. Orifices with cross-section areas A1, A4 correspond to the ring end gaps, whereas orifices with cross-sections A2, A3, A5, A6 correspond to ring-side crevices. Due to typical construction of two lip ring, it was assumed that the gas pressure around the ring surfaces is the same.

It was also assumed that the gas flow through orifices is isentropic (depending on pressure ratio - subsonic or sonic). The heat transfer among gas volume regions and surrounding walls was taken into account.

Thermal expansions of piston and cylinder liner and wear of cylinder liner were taken into account. Leaks between piston rings and cylinder liner were defined by flow areas of ring end gaps, which depend on a position of piston in cylinder.

In addition the mathematical description takes into account the changes of defined gas volume regions and crosssection areas between the rings and piston grooves (due to axial movement of the rings) $[5,10,13,15]$.

For the mathematical modelling of described phenomena the following equations of fundamental physical laws have been applied (here given for a chosen gas volume region Vol):

Equation of mass balance:

$$
\mathrm{dm}_{\mathrm{Vol}}=\sum_{\mathrm{i}} \mathrm{dm}_{\mathrm{In}_{\mathrm{i}}}-\sum_{\mathrm{j}} \mathrm{dm}_{\text {Out }_{\mathrm{j}}}
$$

Equation of energy balance:

$$
\begin{aligned}
& \sum_{\mathrm{i}} \mathrm{dm}_{\text {In }_{\mathrm{i}}} \cdot \mathrm{i}_{\text {In }_{\mathrm{i}}}-\sum_{\mathrm{j}} \mathrm{dm}_{\mathrm{Out}_{\mathrm{j}}} \cdot \mathrm{i}_{\mathrm{Out}_{\mathrm{j}}}-\delta \mathrm{Q}_{\mathrm{Wall}}= \\
& \mathrm{d}\left(\mathrm{m}_{\mathrm{Vol}} \cdot \mathrm{u}_{\text {Vol }}\right)+\mathrm{p}_{\mathrm{Vol}} \cdot \mathrm{dV}_{\text {Vol }}
\end{aligned}
$$

Gas state equation in a differential form:

$$
\mathrm{dT}_{\mathrm{Vol}}=\mathrm{T}_{\mathrm{Vol}} \cdot\left(\frac{\mathrm{dp}_{\mathrm{Vol}}}{\mathrm{p}_{\mathrm{Vol}}}+\frac{\mathrm{dV}_{\mathrm{Vol}}}{\mathrm{V}_{\mathrm{Vol}}}-\frac{\mathrm{dm}_{\mathrm{Vol}}}{\mathrm{m}_{\mathrm{Vol}}}\right)
$$

where: $\mathrm{m}$ - gas mass, $\mathrm{p}$ - gas pressure, $\mathrm{T}$ - gas temperature, $\mathrm{u}$ - internal gas energy, $\mathrm{i}$ - gas enthalpy, $\mathrm{Q}$ - heat transferred through cylinder walls; $\mathrm{I}_{\mathrm{n}}-$ gas inflow, Out - gas outflow, $\mathrm{i}$ - number of inflow channel, $\mathrm{j}$ - outflow channel number, Vol - analysed gas volume. matematycznego, a także wybranych wyników obliczeń numerycznych funkcjonowania pakietu pierścieni tłokowych samochodowego silnika spalinowego.

\section{Modelowanie funkcjonowania pakietu pierścieni tlokowych}

\subsection{Opracowane podmodele}

Opracowano kompleksowy model pracy pierścieni tłokowych. Składa się on z dwóch głównych modeli: a) przepływu gazu przez uszczelnienie labiryntowe: tłok-pierścienie-cylinder, b) przepływu oleju w szczelinie smarnej pomiędzy pierścieniem a gładzią cylindrową. Oba wspomniane modele są ze sobą sprzężone. Dodatkowo zastosowano podmodele następujących zjawisk mechanicznych: kontaktu chropowatych powierzchni, osiowych przemieszczeń pierścieni w rowkach tłoka oraz sprężystych odkształceń kątowych pierścieni.

\subsection{Model przepływu gazu przez uszczelnienie labi- ryntowe pierścieni tlokowych}

Model przepływu gazu $[13,15]$ składa się z kilku stref objętościowych (V1, V2, ..., V5), połączonych ze sobą kanałami dławiącymi o przekrojach A1, A2, ..., A6 (rys. 1). Objętości V3, V5 reprezentują objętości między pierścieniami tłokowymi, a objętości V2, V4 dotyczą objętości rowków tłoka za pierścieniami. Szczeliny o przekrojach A1, A4 reprezentują zamki pierścieni, a przewężenia o przekrojach A2, A3, A5, A6 dotyczą szczelin pomiędzy pierścieniami i rowkami tłoka. $Z$ uwagi na typową konstrukcję dwuwargowego pierścienia (zgarniającego), założono, że ciśnienie gazu wokół powierzchni pierścienia jest jednakowe.
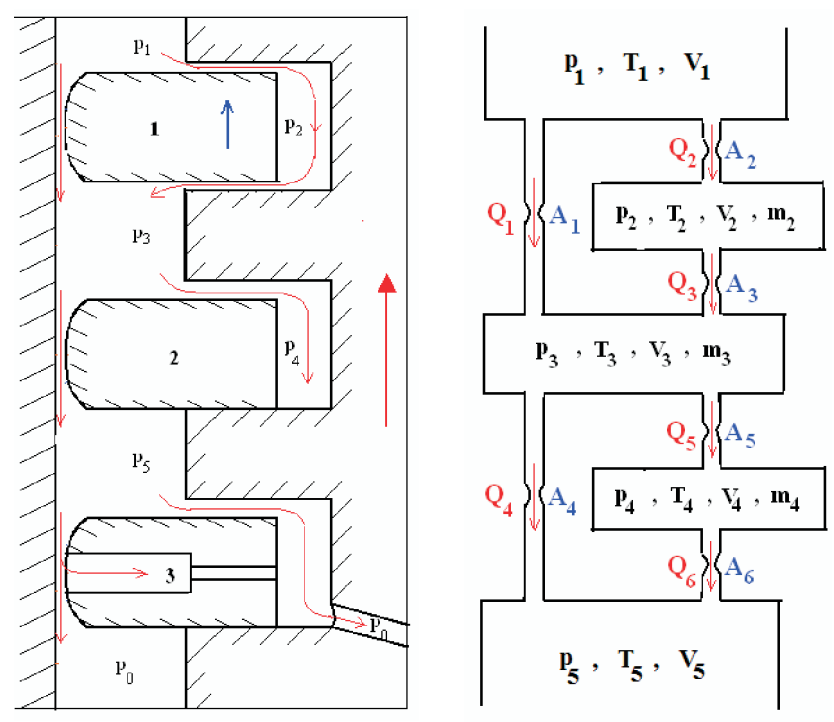

Fig. 1. Scheme of gas flow through the labyrinth seal: piston-ringscylinder and the applied physical model for a four stroke engine with three piston rings

Rys. 1. Schemat przeplywu gazu przez układ labiryntowy: tłok-pierścienie-cylinder oraz model fizyczny dla pakietu 3 pierścieni tłokowych silnika czterosuwowego

Przyjęto, że przepływ przez szczeliny jest izentropowy (w zależności od stosunku ciśnień podkrytyczny, bądź krytyczny). Uwzględniono wymianę ciepła pomiędzy gazem i ściankami przyjętych stref objętościowych. 


\subsection{Model of oil flow in a gap (with rough surfaces)} between the ring and cylinder

Two main cases of oil flow in the system piston ring cylinder liner are presented in Fig. 2.

A one dimensional form of the average Reynolds equation developed by Patir and Cheng $[6,7]$ has been used to calculate hydrodynamic forces in the case of rough gap surfaces. This equation is applicable to any general roughness structure and takes the following form:

$$
\frac{\partial}{\partial x}\left(\phi_{x} \frac{h^{3}}{12 \mu} \frac{d \bar{p}}{d x}\right)=\frac{u}{2} \frac{d \bar{h}_{T}}{d x}+\frac{u}{2} \sigma \frac{d \phi_{S}}{d x}+\frac{d \bar{h}_{T}}{d t}
$$

where: $\mathrm{t}$ - time, $\mathrm{x}$ - coordinate along cylinder liner, $\mathrm{h}$ - nominal oil film thickness, $h_{\mathrm{T}}$ - average separation, $\mathrm{p}$ - hydrodynamic pressure, $\mathrm{u}-$ axial piston velocity, $\mu$ - oil dynamic viscosity, $\mathrm{v}=\partial \mathrm{h} / \partial \mathrm{t}$ - radial piston velocity, $\sigma-$ composite root-mean-square roughness of both mating surfaces.

The significance and mathematical description of empirical coefficients $\phi_{x}, \phi_{\mathrm{S}}$ and boundary conditions of equation (4) are presented in [6, 7] and also in [12].

Effects of interacting asperities of piston ring and cylinder liner surfaces were modelled using the mathematical model developed by Greenwood and Tripp [3], which was precisely described in the publication [12] of the author of this article.
Uwzględniono także odkształcenia termiczne tłoka i ścianki cylindra oraz zużycie gładzi cylindrowej. Szczeliny przepływowe między pierścieniami tłokowymi i ścianką cylindra zdefiniowano jako przekroje przepływowe zamków pierścieni, które zależą od położenia tłoka w cylindrze.

Opis matematyczny uwzględnia ponadto zmienność objętości zdefiniowanych stref oraz wielkości szczelin pomiędzy pierścieniami i rowkami tłoka (wskutek pionowych przemieszczeń pierścieni) $[5,10,13,15]$.

$\mathrm{W}$ modelowaniu matematycznym opisanych zjawisk wykorzystano następujące równania podstawowych praw fizyki (tu: zapisane dla wybranej strefy objętościowej Vol): równanie zachowania masy (1), równanie zachowania energii (2), równanie stanu gazu w formie różniczkowej (3), gdzie: $\mathrm{m}$ - masa gazu, p - ciśnienie gazu, T - temperatura gazu, $\mathrm{u}$ - energia wewnętrzna gazu, i - entalpia gazu, Q - ciepło wymienione przez ścianki cylindra; In - dopływ gazu, Out - odpływ gazu, i - numer kanału dopływowego, j - numer kanału odpływowego, Vol - analizowana strefa objętościowa.

\subsection{Model przepływu oleju w szczelinie (o ściankach} chropowatych) pomiędzy pierścieniem i cylindrem

Dwa główne przypadki przepływu oleju w układzie pierścień tłokowy-gładź cylindrowa przedstawiono na rys. 2.

Do wyznaczenia sił hydrodynamicznych użyto zmodyfikowanego równania Reynoldsa (dla jednowymiarowego przepływu lepkiego) podanego po raz pierwszy przez Patira i Chenga [6, 7]. Równanie to ma zastosowanie do każdego przypadku uwzględniającego chropowatość powierzchni i przyjmuje postać (4), przy czym: $\mathrm{t}$ - czas, $\mathrm{x}$ - współrzędna wzdłuż cylindra, $\mathrm{h}$ - nominalna grubość filmu olejowego, $\mathrm{h}_{\mathrm{T}}$ - średnia wysokość szczeliny, p - ciśnienie hydrodynamiczne, $\mathrm{u}$ - osiowa prędkość tłoka, $\mu$ - lepkość dynamiczna oleju, $\mathrm{v}=\partial \mathrm{h} / \partial \mathrm{t}-$ promieniowa prędkość pierścienia, $\sigma$ - średnie odchylenie kwadratowe złożonej chropowatości obu współpracujących powierzchni.

Znaczenie i opis matematyczny empirycznych współczynników $\phi_{\mathrm{x}} \mathrm{i} \phi_{\mathrm{S}}$ oraz warunków brzegowych równania (4) podano $\mathrm{w}[6,7,12]$.

\subsection{Model of ring's torsional deformation and ring's axial movement in a piston groove}

In Figure 3 a scheme of forces acting on piston rings, action lines and distances between these forces and the centre of gravity $\mathrm{S}$ of the ring cross-section for one and two lip ring types are shown.

Typical set of equations for a single lip piston ring has the following form:

a) in radial direction:

$$
\Sigma \mathrm{F}_{\mathrm{r}}=\mathrm{F}_{\mathrm{h}}+\mathrm{F}_{\mathrm{c}}+\mathrm{F}_{\mathrm{yg}} \mathrm{i}_{\mathrm{i}+1}+\mathrm{F}_{\mathrm{yg}}-\mathrm{F}_{\mathrm{spr}}-\mathrm{F}_{\text {gas }}=0
$$

Efekty oddziaływania pomiędzy nierównościami powierzchni pierścienia i gładzi cylindra modelowano przy użyciu modelu matematycznego opracowanego przez Greenwooda i Trippa [3], co opisano dokładnie w publikacji [12].

\subsection{Model odkształceń kątowych pierścieni i osiowych przemieszczeń pierścieni $w$ rowkach tloka}

Na rysunku 3 przedstawiono schemat sił działających na pierścienie tłokowe, kierunki i ramiona ich działania $\mathrm{w}$ stosunku do środka ciężkości S przekroju pierścienia jedno- i dwuwargowego. 
where: $\mathrm{F}_{\mathrm{h}}$ - hydrodynamic normal force, $\mathrm{F}_{\mathrm{c}}$ - elastic direct rough surface contact normal force, $\mathrm{F}_{\mathrm{spr}}$ - ring spring force, $\mathrm{F}_{\text {gas }}$ - back ring gas force, $\mathrm{F}_{\text {ygi+1 }}$ - trailing edge gas force, $\mathrm{F}_{\text {ygi }}^{\text {gas }}$ - leading edge gas force.

b) in axial direction:

$$
\Sigma \mathrm{F}_{\mathrm{x}}=\mathrm{R}_{\mathrm{x}}-\mathrm{F}_{\text {fri }}-\mathrm{F}_{\mathrm{cx}}+\mathrm{F}_{\mathrm{g}_{\mathrm{i}+1}}-\mathrm{F}_{\mathrm{g}_{\mathrm{i}}}-\frac{\mathrm{m}}{\mathrm{c}_{\mathrm{imc}}}\left(\mathrm{g}+\mathrm{b}_{\mathrm{k}}\right)=0
$$

where: $\mathrm{R}_{\mathrm{x}}$ - groove reaction force, $\mathrm{F}_{\text {fri }}-$ viscous friction force, $F_{c x}$ - contact friction force, $\mathrm{F}_{\mathrm{gi}+1}$ - trailing side gas force, $\mathrm{F}_{\mathrm{gi}}$ - leading side gas force, $\mathrm{m}$ - ring mass, $\mathrm{g}$ - gravitational acceleration, $\mathrm{b}_{\mathrm{k}}$ - piston acceleration, $\mathrm{c}_{\text {imc }}$ - ring circumference.

Using these equations, we can calculate the reaction force between the ring and ring-groove in every time step. If the sign of this force changes, the axial movement of the ring in the ring-groove begins. At this point, the value of the reaction force $R_{x}=0$ and the axial movement of the ring relative to the piston groove can be described by the following differential equation:

$$
\frac{m}{c_{i m c}} \frac{d^{2} x_{r}}{d t^{2}}=-F_{\text {fri }}-F_{c x}+F_{g_{i+1}}-F_{g_{i}}-\frac{m g}{c_{i m c}}
$$

The ring movement $\mathrm{x}_{\mathrm{r}}$ is finished if the ring reaches the other side of the ring-groove.

The twist around the centre of gravity of the ring crosssection (point $\mathrm{S}$ in Fig. 3) can be described by the following momentum balance:

$$
\begin{aligned}
& \Sigma \mathrm{M}_{\mathrm{S}}=\mathrm{F}_{\mathrm{h}}\left(\mathrm{x}_{\mathrm{S}}-\mathrm{x}_{\mathrm{F}_{\mathrm{h}}}\right)+\mathrm{F}_{\mathrm{c}}\left(\mathrm{x}_{\mathrm{S}}-\mathrm{x}_{\mathrm{F}_{\mathrm{c}}}\right)-\left(\mathrm{F}_{\mathrm{fri}}+\mathrm{F}_{\mathrm{cx}}\right) \cdot \frac{\mathrm{A}_{\mathrm{r}}}{2}+ \\
& +\left(\mathrm{F}_{\mathrm{g}_{\mathrm{i}+1}}-\mathrm{F}_{\mathrm{g}_{\mathrm{i}}}\right)\left(\frac{\mathrm{y}}{2}+\mathrm{y}_{\mathrm{sc}}\right)+\mathrm{R}_{\mathrm{x}} \cdot \mathrm{y}_{\mathrm{sc}}-\mathrm{K} \cdot \theta=0
\end{aligned}
$$

Predicting the ring torsional stiffness $\mathrm{K}$ (according to equation given in the paper [14]) and using the momentum balance equation (8), the ring twist angle $\theta$ can be calculated.

\section{Experimental verification of developed models}

\subsection{Preliminary evaluation of developed models and computer code}

The general properties of the worked out model and computer programme concerning hydro-dynamics and
Typowy układ równań dla jednowargowego pierścienia tłokowego ma postać:

a) w kierunku promieniowym (5), gdzie: $F_{h}-$ siła normalna hydrodynamiczna, $\mathrm{F}_{\mathrm{c}}$ - siła normalna kontaktu z chropowatościami powierzchni, $\mathrm{F}_{\mathrm{spr}}$ - siła sprężystości pierścienia, $\mathrm{F}_{\text {gas }}$ - siła gazowa rozpierająca pierścień, $\mathrm{F}_{\text {ygi }}, \mathrm{F}_{\text {ygi+1 }}$ - siły gazowe odpowiednio na przedniej i tylnej części powierzchni ślizgowej pierścienia,

b)
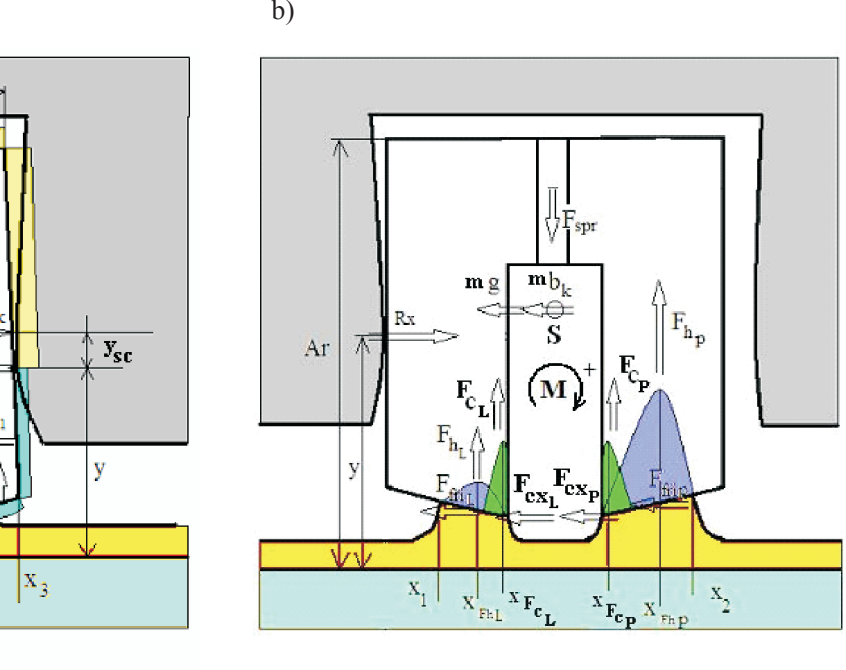
ring, b) oil ring with two lips

or scraper ring as a single lip

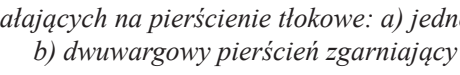

b) w kierunku osiowym (6), gdzie: $\mathrm{R}_{\mathrm{x}}$ - siła reakcji ścianki rowka, $\mathrm{F}_{\text {fri }}$ - siła tarcia lepkiego, $\mathrm{F}_{\mathrm{cx}}$ - siła styczna kontaktu z nierównościami powierzchni, $\mathrm{F}_{\mathrm{gi}}, \mathrm{F}_{\mathrm{gi}+1}$ - siły gazowe odpowiednio na przedniej i tylnej części powierzchni ślizgowej pierścienia, $\mathrm{m}$ - masa pierścienia, $\mathrm{g}$ - przyspieszenie ziemskie, $b_{k}$ - przyspieszenie tłoka, $c_{\text {imc }}$ - obwód pierścienia.

$\mathrm{Z}$ powyższego równania obliczana jest siła reakcji $\mathrm{R}_{\mathrm{x}}$ między pierścieniem i półką rowka tłoka. Zmiana zwrotu tej siły oznacza rozpoczęcie przeskoku pierścienia w rowku. Wówczas wartość siły reakcji $\mathrm{R}_{\mathrm{x}}=0$ i osiowy ruch pierścienia względem tłoka może być opisany równaniem różniczkowym (7).

Przemieszczenie $\mathrm{x}_{\mathrm{r}}$ pierścienia kończy się po osiągnięciu przez niego kontaktu z sąsiednią półką rowka.

Odkształcenie kątowe względem środka ciężkości przekroju pierścienia (punkt S na rys. 3) może być opisane przez równanie równowagi momentów (8).

Wyznaczając sztywność skrętną K pierścienia (według związku podanego w artykule [14]), można, w oparciu o równanie równowagi momentów (8), obliczyć kąt $\theta$ jego kątowego odkształcenia.

\section{Weryfikacja eksperymentalna opracowanych modeli}

\subsection{Wstępna ocena opracowanych modeli i oprogra- mowania}

Ogólne właściwości opracowanego modelu i programu komputerowego dotyczącego hydrodynamiki i przepływu 
oil flow were verified for chosen calculation examples. It was carried out by a comparison of calculation results of an own programme STOPF with the results of programme LUB that was used by the marine engine designing centre Wärtsilä (in Winterthur in Switzerland) several years ago. This work was done during one of many research periods of the author at mentioned company. Some examples of the hydrodynamic system: scraper rings - piston rod were analysed. A very good compatibility of compared calculation results was achieved.

\subsection{Range of experimental investigations determining the basis of verification}

A verification of the simulation model has been done by the author of this article for two marine Diesel internal combustion engines. One (of smaller dimensions) is a fourstroke engine and the other is a two-stroke engine. This work was done during the author's several research periods at previously mentioned engine designing centre Wärtsilä. At request of this company, the types of experimentally tested engines have not been given.

In order to carry out the verification of the developed model of gas flow through the labyrinth seal, the measurement results of unsteady gas pressures in cylinder, among piston rings and in crankcase (using piezoelectric sensors mounted in the piston) were compared with appropriate calculation results. In addition for the four-stroke engine experimental results of axial movement of rings in piston grooves (applying inductive sensors in the piston) and of gas blow-by to crankcase (using a special flow-meter) were accessible [5].

On the other hand, the experimental verification of a hydrodynamic model of piston rings involved a comparison of measurement results of scraped oil volumes by a gland-box of a two-stroke marine engine with appropriate calculation results. Unfortunately, similar measurements for piston ring packs of tested engines were not carried out.

\subsection{Determination of the set of model parameters}

The technical data of tested engines (for instance: main dimensions, rotational speed of maximal power etc.) were taken from the technical documentation that was made available to the author by the engine designing centre Wärtsilä. The same occurred in the case of geometrical parameters of the system piston-rings-cylinder. They concerned dimensions of piston rings (including microprofiles of sliding surfaces - for new or worn out piston rings), chosen mechanical parameters of piston rings (for example: masses, elasticity forces), piston dimensions (including ring grooves), cylinder dimensions (including among other things surface roughness).

Data concerning thermomechanical deformations of piston and cylinder liner (at full engine load) were also made available to the author by the engine designing centre. They concerned calculation results of strength of materials for mentioned engine parts with the use of finite element method. The wear of cylinder liner (including 1000 hours of engine running) was evaluated basing on regularly conducted experimental tests by the engine designing centre Wärtsilä. oleju zweryfikowano dla wybranych przypadków obliczeniowych. Polegało to na porównaniu wyników obliczeń własnego programu o nazwie STOPF z rezultatami uzyskiwanymi za pomocą programu komputerowego o nazwie LUB używanego przed kilkoma laty w ośrodku konstrukcyjnym silników okrętowych Wärtsilä (w Winterthur, w Szwajcarii). Pracę tę wykonano w ramach jednego z licznych okresów pracy badawczej autora we wspomnianej firmie. Przeanalizowano kilka przypadków układu hydrodynamicznego: pierścienie zgarniające-tłoczysko. Uzyskano bardzo dobrą zgodność porównywanych wyników obliczeń.

\subsection{Zakres badań eksperymentalnych stanowiących podstawę weryfikacji}

Weryfikację modelu symulacyjnego przeprowadzono dla dwóch okrętowych silników spalinowych o zapłonie samoczynnym. Pierwszy z nich (o mniejszych wymiarach) to silnik czterosuwowy, a drugi - dwusuwowy. Prace te wykonano we wcześniej wspomnianym ośrodku konstrukcyjnym Wärtsilä. Zgodnie z życzeniem tego ośrodka, nie podano oznaczenia typów silników, których dotyczą wyniki badań eksperymentalnych.

W celu przeprowadzenia weryfikacji opracowanego modelu przepływu gazu przez uszczelnienie labiryntowe pierścieni, porównano wyniki pomiarów nieustalonego ciśnienia gazu w cylindrze silnika, między pierścieniami oraz w skrzyni korbowej (przy użyciu czujników piezoelektrycznych zamontowanych w tłoku) ze stosownymi wynikami obliczeń. Dla silnika czterosuwowego dostępne były ponadto wyniki pomiarów osiowych przemieszczeń pierścieni w rowkach tłoka (z zastosowaniem czujników indukcyjnych w tłoku), a także natężenia przedmuchu gazu do skrzyni korbowej (przy użyciu specjalistycznego przepływomierza) [5].

Natomiast weryfikacja eksperymentalna modelu hydrodynamiki pierścieni dotyczyła porównania wyników pomiarów objętości zgarnianego oleju przez dławnicę dwusuwowego silnika okrętowego ze stosownymi wynikami obliczeń. Niestety nie były wykonywane analogiczne pomiary dla pakietów pierścieni tłokowych badanych silników.

\subsection{Określenie zbioru parametrów modeli}

Dane techniczne badanych silników (np. wymiary główne, prędkość obrotową odpowiadającą maksymalnej mocy itp.) zaczerpnięto $\mathrm{z}$ dokumentacji technicznej udostępnionej autorowi przez ośrodek konstrukcyjny silników Wärtsilä. Tak samo postąpiono w przypadku parametrów geometrycznych układu tłok-pierścienie-cylinder. Obejmowały one: wymiary pierścieni (w tym mikroprofile ich powierzchni współpracujących z cylindrem - dla pierścieni nowych, bądź zużytych), wybrane parametry mechaniczne pierścieni (np. masy, siły sprężystości), wymiary tłoka (w tym rowków pierścieniowych), wymiary cylindra (w tym m.in. chropowatość powierzchni).

Dane dotyczące odkształceń termomechanicznych tłoka i tulei cylindrowej (dla pełnego obciążenia silnika) udostępnił także ośrodek konstrukcyjny silników. Stanowiły one wyniki obliczeń wytrzymałościowych wspomnianych części z użyciem metody elementów skończonych. Zużycie 
The basic thermodynamic data of the engine (for example: gas pressure and temperature in cylinder and in crankcase, average temperatures of piston rings, thermal state of piston and cylinder surface etc.) were also made available. These data had been obtained as calculation or experimental results. In addition the engine designing company provided information concerning physical properties of oil (for example temperature-dependence of oil viscosity).

A lot of important information has been gathered from the literature $[5,10]$. Among other things, it concerned thermodynamic and flow parameters, such as gas flow coefficients through the canals of the labyrinth piston-rings- cylinder, heat transfer coefficients between gas and walls of this labyrinth etc. The final selection of these parameters values was done by taking into account the known compatibility criteria of numerical calculations and experimental results.

\subsection{Compatibility criteria of simulation}

and experimental results

As compatibility criteria of numerical simulation and experimental results the farther mentioned parameters were assumed [1]. They mainly concern function variations versus crank angle of an internal combustion engine.

Mean square deviation of measured and calculated function:

$$
\sigma=\sqrt{\frac{1}{n} \sum_{i=1}^{n}\left[f_{\text {meas }}\left(x_{i}\right)-f_{\text {calc }}\left(x_{i}\right)\right]^{2}}
$$

where: $f_{\text {meas }}$ - value of compared function for $i-$ th value of argument $\mathrm{x}$ (for instance: time t, crank angle $\alpha, \mathrm{x}$ - coordinate along cylinder liner) obtained from measurements, $f_{\text {calc }}$ - value of compared function for $i$ - th value of argument $x$ obtained from numerical calculation, $\mathrm{n}$ - number of points of analysed function $\mathrm{f}_{\text {meas/calc }}(\mathrm{x})$.

a) Maximum value of differences between measured and calculated functions:

$$
\Delta \mathrm{f}_{\max }=\max _{\mathrm{i}=1}^{\mathrm{n}}\left[\mathrm{f}_{\text {meas }}\left(\mathrm{x}_{\mathrm{i}}\right)-\mathrm{f}_{\text {calc }}\left(\mathrm{x}_{\mathrm{i}}\right)\right]
$$

b) Pearson's linear correlation coefficient of measured and calculated function:

$$
r_{\text {meas } / \text { calc }}=\frac{\sum_{i=1}^{n}\left[f_{\text {meas }}\left(x_{i}\right)-f_{\text {meas }}^{\text {av }}\right] \cdot\left[f_{\text {calc }}\left(x_{i}\right)-f_{\text {calc }}^{\text {av }}\right]}{\sqrt{\sum_{i=1}^{n}\left[f_{\text {meas }}\left(x_{i}\right)-f_{\text {meas }}^{\text {av }}\right]^{2} \cdot \sum_{i=1}^{n}\left[f_{\text {calc }}\left(x_{i}\right)-f_{\text {calc }}^{\text {av }}\right]^{2}}}
$$

where: $f_{\text {meas }}^{\text {av }}$ - average value of measured function, $\mathrm{f}_{\text {calc }}^{\text {av }}-$ average value of calculated function.

\subsection{Experimental verification of operation quality of the models}

\subsubsection{Gas flow through the labyrinth seal of a four-stroke engine}

A four-stroke marine engine of Wärtsilä company was tested as regards gas flow through the labyrinth seal of piston rings. At request of this company, the variations gładzi cylindrowej (przypadające na 1000 godzin pracy silnika) wyznaczono na podstawie regularnie prowadzonych badań eksperymentalnych przez ośrodek konstrukcyjny silników Wärtsilä. Udostępniono także podstawowe dane termodynamiczne silnika (np. ciśnienie i temperaturę gazu w cylindrze i skrzyni korbowej, średnie temperatury pierścieni tłokowych, stan cieplny powierzchni tłoka i cylindra itp.). Dane te uzyskano w wyniku obliczeń względnie badań eksperymentalnych. Ponadto firma konstrukcyjna silników zapewniła informacje dotyczące właściwości fizycznych oleju (np. zależność jego lepkości od temperatury).

Wiele istotnych informacji zaczerpnięto ze źródeł literaturowych $[5,10]$. Dotyczyły one między innymi parametrów termodynamiczno-przepływowych, takich jak: współczynniki przepływu gazu przez kanały labiryntu tłok- pierścienie-cylinder, współczynniki przejmowania ciepła między gazem i ściankami tego labiryntu itp. Ostatecznego doboru wartości tych parametrów dokonano, kierując się znanymi kryteriami zgodności wyników obliczeń symulacyjnych i badań eksperymentalnych.

\subsection{Kryteria zgodności wyników badań symulacyjnych i eksperymentalnych}

Jako kryteria zgodności wyników obliczeń symulacyjnych i badań eksperymentalnych przyjęto wymienione dalej wielkości [1]. Dotyczą one głównie przebiegów w funkcji kąta obrotu wału korbowego silnika spalinowego.

a) Średnie odchylenie kwadratowe przebiegu zmierzonego i obliczonego wyraża wzór (9), gdzie: $f_{\text {meas }}$ - wartość porównywanej funkcji dla i-tej wartości argumentu x (np. czasu t kąta obrotu wału korbowego $\alpha$, współrzędnej x wzdłuż gładzi cylindrowej) otrzymana w wyniku przeprowadzonych pomiarów, $\mathrm{f}_{\text {calc }}$ - wartość porównywanej funkcji dla i-tej wartości argumentu x uzyskana w wyniku przeprowadzonych obliczeń symulacyjnych, n - liczba punktów analizowanej funkcji $\mathrm{f}_{\text {meas/calc }}(\mathrm{x})$.

b) Wartość maksymalna różnic przebiegów zmierzonych i obliczonych - wzór (10).

c) Współczynnik korelacji liniowej Pearsona przebiegu zmierzonego i obliczonego (11), gdzie: $\mathrm{f}_{\text {meas }}^{\text {av }}$ - wartość średnia przebiegu zmierzonego, $\mathrm{f}_{\text {calc }}^{\text {av }}$ - wartość średnia przebiegu obliczonego.

\subsection{Weryfikacja eksperymentalna jakości pracy modeli}

\subsubsection{Przepływ gazu przez uszczelnienie labiryntowe silnika czterosuwowego}

Czterosuwowy silnik okrętowy firmy Wärtsilä zbadano pod względem przepływu gazu przez uszczelnienie labiryntowe pierścieni tłokowych. Zgodnie z życzeniem tej firmy, przebiegi ciśnień gazu oraz osiowe przemieszczenia pierścieni przedstawiono jako wielkości bezwymiarowe $\left(\mathrm{p} / \mathrm{p}_{\max }\right.$ oraz $\mathrm{x} / \mathrm{x}_{\max }$ ) odniesione do wartości maksymalnych (odpowiednio ciśnienia $\mathrm{p}_{\max } \mathrm{w}$ cylindrze oraz luzu osiowego $\mathrm{x}_{\max }$ danego pierścienia $\mathrm{w}$ rowku tłoka). $\mathrm{Z}$ tego względu nieznane dla czytelnika pozostają wartości $\mathrm{p}_{\max }$ oraz $\mathrm{x}_{\max }$.

Na rysunku 4 pokazano przebieg względnych zmian ciśnienia gazu w pakiecie pierścieni tłokowych czterosuwowego silnika Wärtsilä w funkcji kąta obrotu wału korbowego. 
of gas pressure and axial movement of rings in piston grooves are presented as dimensionless parameters $\left(\mathrm{p} / \mathrm{p}_{\max }\right.$ and $\left.\mathrm{x} / \mathrm{x}_{\max }\right)$ related to maximum values (of pressure pmax in cylinder and axial clearance $\mathrm{x}_{\max }$ of the ring in a piston groove). Therefore the values of $\mathrm{p}_{\max }$ and $\mathrm{x}_{\max }$ are not known for the reader.

In Figure 4 variations of relative gas pressure in a piston ring pack of the Wärtsilä four-stroke engine as a function of crank angle are shown. The numerical calculation is done on the basis of known cylinder pressure variation and gas leakage through the labyrinth sealing of the piston ring pack (orifices corresponding ring end gaps and ring-side crevices).

Then in Fig. 5 a comparison of dimensionless gas pressure $\mathrm{p}_{3} / \mathrm{p}_{\max }$ (measured and calculated) for the volume region between piston rings 1 and 2 (Fig. 1) as a function of crank angle is presented. However in Tab. 1 appropriate parameters that characterize this comparison are presented. The values of these parameters prove that a satisfactory compatibility of the analysed variation of gas pressure has been achieved. A small discrepancy between the values of measurements and calculations mainly results from simplification assumptions of the model (chapter 2.1) and possible errors of measurements and signal recording.

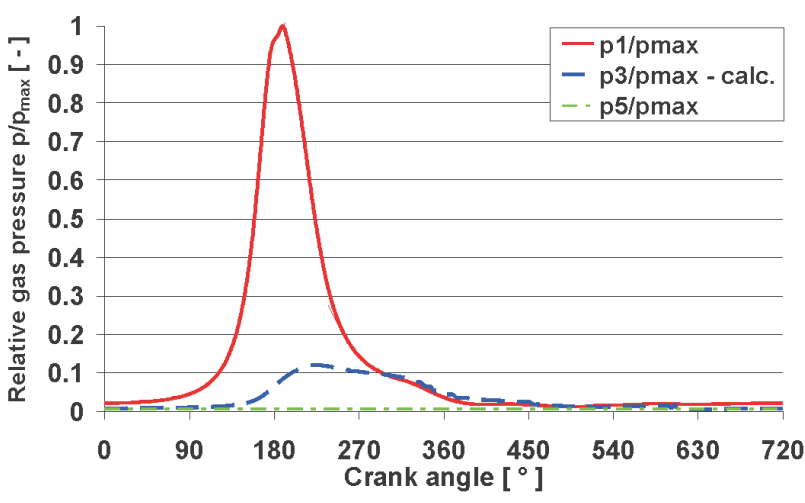

Fig. 4. Relative gas pressure variations versus crank angle: $p_{1} / p_{\max }-$ in combustion chamber, $\mathrm{p}_{3} / \mathrm{p}_{\max }$ - among the $1^{\text {st }}$ and $2^{\text {nd }}$ piston ring (calculated), $\mathrm{p}_{5} / \mathrm{p}_{\max }-$ in crankcase

Rys. 4. Przebiegi zmienności względnych ciśnień gazu w funkcji kąta obrotu watu korbowego: $p_{I} / p_{\max }-w$ cylindrze, $p_{3} / p_{\max }-$ między pierścieniami 1 i 2 (obliczone), $p_{5} / p_{\max }-w$ skrzyni korbowej

In Figure 6 a comparison of (measured and calculated) relative axial movement $\mathrm{x}_{1} / \mathrm{x}_{\max }$ of the first piston ring (compression ring) in the piston groove as a function of crank angle is shown. Chosen parameters that characterize this comparison are presented in Tab. 2. A small time lag between both piston ring movements (measured and calculated) of this piston ring is observed. Nevertheless, a satisfactory qualitative compatibility of both compared functions has been achieved.
Obliczenia numeryczne przeprowadzono w oparciu o znany przebieg zmian ciśnienia gazu w cylindrze i przedmuchów gazu przez uszczelnienie labiryntowe pakietu pierścieni tłokowych (szczeliny przepływowe zamków pierścieni oraz między pierścieniami i rowkami tłoka).

$\mathrm{Na}$ rysunku 5 przedstawiono porównanie względnych zmian ciśnienia gazu $\mathrm{p}_{3} / \mathrm{p}_{\max }$ (zmierzonych $\mathrm{i}$ obliczonych) dla strefy objętościowej między pierścieniami 1 i 2 (rys. 1) w funkcji kąta obrotu wału korbowego silnika. W tabeli 1 zamieszczono natomiast stosowne wielkości charakteryzujące to porównanie. Świadczą one o uzyskaniu zadowalającej zgodności analizowanego przebiegu ciśnienia gazu. Niewielka rozbieżność między wynikami pomiarów i obliczeń wynika głównie z uproszczeń przyjętych w modelu (podrozdz. 2.1) oraz ewentualnych błędów pomiaru i rejestracji sygnałów.

Na rysunku 6 zaprezentowano porównanie względnego osiowego przemieszczenia $\mathrm{x}_{1} / \mathrm{x}_{\max }$ (zmierzonego i obliczonego) pierścienia 1 (uszczelniającego) w obrębie rowka tłoka w funkcji kąta obrotu wału korbowego. Wybrane wielkości charakteryzujące to porównanie przedstawiono $\mathrm{w}$ tab. 2. Obserwuje się nieznaczne przesunięcie czasowe przemieszczenia (zmierzonego i obliczonego) dla tego pierścienia. Mimo to uzyskano wystarczająco dobrą zgodność jakościową obu porównywanych przebiegów.

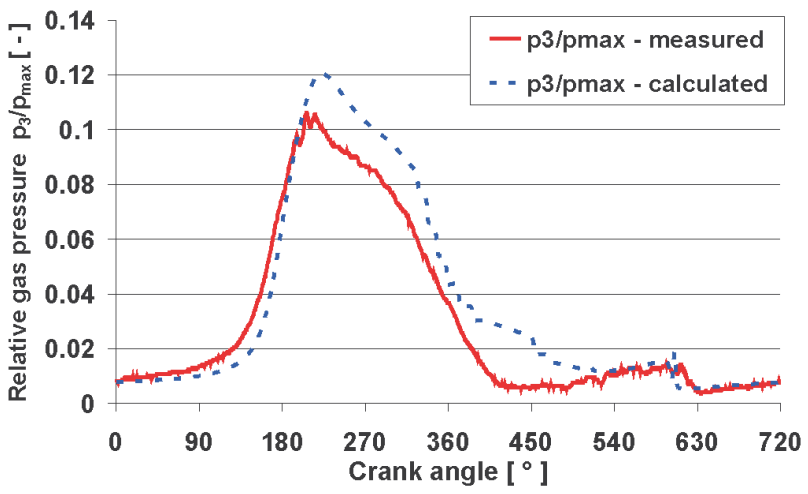

Fig. 5. Comparison of relative gas pressure variation $\mathrm{p}_{3} / \mathrm{p}_{\max }$ (measured and calculated) in the volume between the $1^{\text {st }}$ and $2^{\text {nd }}$ piston ring (Fig. 1) as a function of crankshaft rotation

Rys. 5. Porównanie relatywnego ciśnienia gazu $p_{3} / p_{\max }$ (zmierzonego i obliczonego) w objętości między pierścieniami 1 i 2 (rys. 1) w funkcji kata obrotu watu korbowego

Wynik pomiaru wykazuje jednak pewną nieścisłość. Przy przeskoku pierścienia do górnej półki rowka jego względny wznios $\mathrm{x}_{1} / \mathrm{x}_{\max }$ przyjmuje wartość większą niż 1 . Ponadto przy powrocie do dolnej półki rowka tłoka względny wznios pierścienia jest mniejszy od 0 . Świadczy to o przekroczeniu nominalnego osiowego luzu pierścienia w rowku tłoka. Potencjalną przyczyną tego może być niedokładność pomiaru wynikająca $\mathrm{z}$ trudności wyznaczenia przemieszczenia pierścienia w czasie posuwisto-zwrotnego ruchu tłoka.

Następną porównywaną wielkością jest natężenie przepływu gazu przez uszczelnienie labiryntowe pierścieni tłokowych do skrzyni korbowej silnika. W tabeli 3 zestawiono zmierzone i obliczone wartości przedmuchów spalin 
Table 1. Compatibility of relative gas pressure $\mathrm{p}_{3} / \mathrm{p}_{\max }$ variations (measured and calculated)

Tabela 1. Zgodność przebiegów zmienności relatywnego ciśnienia gazu $p_{3} / p_{\max }$ (zmierzonego i obliczonego)

\begin{tabular}{|c|c|c|c|}
\hline $\begin{array}{c}\text { Relative difference of maximal } \\
\text { values (measured and calculated)/ } \\
\text { względna różnica wartości szczyto- } \\
\text { wych (zmierzonych } \text { i obliczonych) }\end{array}$ & $\begin{array}{c}\text { Ratio of average values (of calcu- } \\
\text { lated and measured results)/stosu- } \\
\text { nek wartości średnich (przebiegu } \\
\text { obliczonego do zmierzonego) }\end{array}$ & $\begin{array}{c}\text { Ratio of mean square deviation to } \\
\text { measured maximal value/stosunek } \\
\text { średniego odchylenia kwadratowego } \\
\text { do zmierzonej wartości szczytowej }\end{array}$ & $\begin{array}{c}\text { Correlation coefficient (of } \\
\text { measured and calculated results)/ } \\
\text { wspótczynnik korelacji (przebiegu } \\
\text { zmierzonego i obliczonego) }\end{array}$ \\
\hline $\mathbf{1 3 . 6} \%$ & $\mathbf{1 . 1 8}$ & $\mathbf{1 0 . 7 7 \%}$ & $\mathbf{0 . 9 8}$ \\
\hline
\end{tabular}

But the measurement result shows a certain inaccuracy. In case of the piston ring jumping to the upper shelf of piston groove, the relative lift $\mathrm{x}_{1} / \mathrm{x}_{\max }$ of the ring shortly exceeds the value 1 . In addition, when coming back to the lower shelf of piston groove, the relative lift of the ring is lower than 0 . It proves that the nominal axial clearance of the ring in piston groove is exceeded. The possible reason of this fact might be the measurement inaccuracy, which results from difficulties in determining the ring movement during the reciprocating motion of the piston.

The next compared parameter is a gas blow-by through the labyrinth seal of piston rings into the engine crankcase. In Tab. 3 the measured and calculated values of the exhaust gas blow-by and the quotient of the calculated to measured value are given. A very good compatibility of both results has been achieved.

\subsubsection{Volumes of scraped oil by gland-box of a two-stroke marine engine}

The next engine used for the verification was a turbocharged two-stroke marine Diesel engine designed by Wärtsilä company [2,8]. This engine is equipped in two seal systems that were included for experimental verification: oraz podano stosunek wielkości obliczonej do zmierzonej. Uzyskano bardzo dobrą zgodność obu wyników.

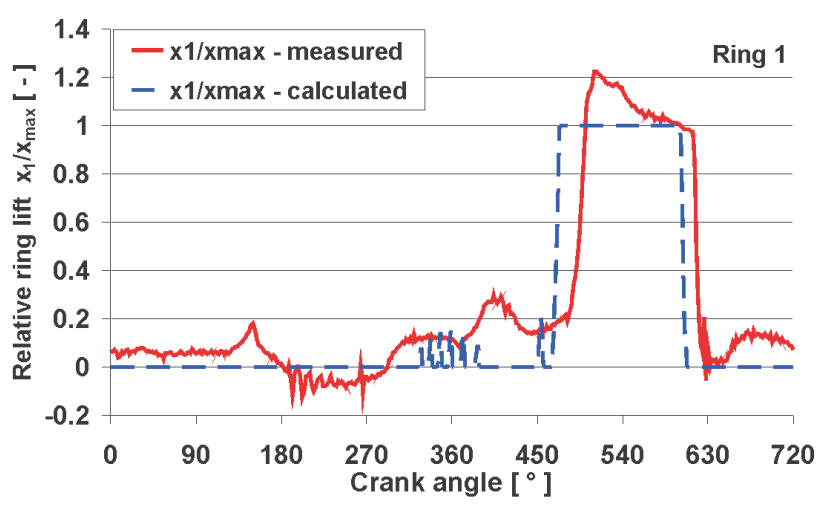

Fig. 6. Comparison of relative ring lift $x_{1} / x_{\max }$ of the $1^{\text {st }}$ (compression) ring in piston groove (measured and calculated) as a function of crankshaft rotation

Rys. 6. Porównanie relatywnego przemieszczenia 1. pierścienia (uszczelniajacego) $w$ rowku tloka $x_{I} / x_{\max }$ (zmierzonego i obliczonego) $w$ funkcji kata obrotu watu korbowego

Table 2. Compatibility of relative ring lift $\mathrm{x}_{1} / \mathrm{x}_{\max }$ in piston groove (measured and calculated)

Taela 2. Zgodność relatywnego przemieszczenia pierścienia $w$ rowku tłoka $x_{I} / x_{\max }$ (zmierzonego i obliczonego)

\begin{tabular}{|c|c|}
\hline $\begin{array}{c}\text { Ratio of average values (of calculated and measured results)/stosunek } \\
\text { wartości średnich (przebiegu obliczonego do zmierzonego) }\end{array}$ & $\begin{array}{c}\text { Correlation coefficient (of measured and calculated results)/współczyn- } \\
\text { nik korelacji (przebiegu zmierzonego i obliczonego) }\end{array}$ \\
\hline 0.75 & 0.86 \\
\hline
\end{tabular}

Table 3. Compatibility of gas blow-by to the engine crankcase (measured and calculated)

Tabela 3. Zgodność przedmuchu gazu do skrzyni korbowej (zmierzonego i obliczonego)

\begin{tabular}{|c|c|c|}
\hline $\begin{array}{c}\text { Measured value/wielkość zmierzona } \\
{\left[\mathrm{dm}^{3} / \mathrm{min}\right]}\end{array}$ & $\begin{array}{c}\text { Calculated value/wielkość obliczona } \\
{\left[\mathrm{dm}^{3} / \mathrm{min}\right]}\end{array}$ & $\begin{array}{c}\text { Quotient of calculated and measured value/stosunek wielkości } \\
\text { obliczonej do zmierzonej }[-]\end{array}$ \\
\hline $\mathbf{8 3 . 1}$ & $\mathbf{8 2 . 2}$ & $\mathbf{0 . 9 8 9}$ \\
\hline
\end{tabular}

a) labyrinth seal of piston rings,

b) pack of seal and scraper rings making a gland-box that separates the piston underside from crankcase of the engine.

In this paper verification results for the gland-box are presented.

The purpose of a gland-box is to separate the piston underside as tight as possible from the crankcase. The engine designing centre Wärtsilä made available to the author measurement results of scraped oil volumes by the glandbox of chosen engine. Special oil tanks were installed in the tested engine, where lubricating oil flew in. Then oil volumes scraped up to piston underside and down to crankcase during 24 hours of engine running were measured.

\subsubsection{Objętości zgarnianego oleju przez dlawnicę dwusuwo-} wego silnika okrętowego

Następnym silnikiem wykorzystywanym przy weryfikacji był dwusuwowy, turbodoładowany silnik okrętowy o zapłonie samoczynnym, skonstruowany w firmie Wärtsilä $[2,8]$. Jest on wyposażony w dwa układy uszczelniające obejmujące zakres przeprowadzonej weryfikacji eksperymentalnej:

a) uszczelnienie labiryntowe pierścieni tłokowych,

b) pakiet pierścieni uszczelniająco-zgarniających stanowiących dławnicę oddzielającą przestrzeń pod tłokiem od skrzyni korbowej silnika.

$\mathrm{W}$ tym artykule przedstawiono jedynie weryfikację wyników dla dławnicy. 
One of many input parameters of the simulation program is the velocity of oil fog deposition on a free surface of piston rod. This parameter has been chosen in such a way that a good compatibility between measured and calculated oil volumes scraped down into crankcase has been achieved. In Table 4 a comparison of measured and calculated parameters and a percent scatter of results are given.
Zadaniem dławnicy jest możliwie szczelne oddzielenie przestrzeni pod tłokiem od skrzyni korbowej silnika. Wyniki pomiarów zgarnianych objętości oleju przez dławnicę wybranego silnika udostępniła Wärtsilä. W badanym silniku zamontowano odpowiednie naczynia, do których spływał olej. Następnie zmierzono objętości oleju zgarniane do góry do przestrzeni pod łłokiem oraz w dół do skrzyni korbowej w ciągu 24 godzin pracy silnika.

Table 4. Compatibility of the scraped oil quantities (measured and calculated) by the gland-box

Tabela 4. Zgodność zgarnianych ilości oleju przez dławnicę (zmierzonych i obliczonych)

\begin{tabular}{|l|c|c|c|}
\hline $\begin{array}{l}\text { Analyzed volumes of lubricating oil/analizowa- } \\
\text { ne objętości oleju smarującego }\end{array}$ & $\begin{array}{c}\text { Average value of measured para- } \\
\text { meter/średnia wartość wielkości } \\
\text { zmierzonej }\left[\mathrm{dm}^{3} / 24 \mathrm{~h}\right]\end{array}$ & $\begin{array}{c}\text { Calculated value/ } \\
\text { wielkość obliczona } \\
{[\mathrm{dm} / 24 \mathrm{~h}]}\end{array}$ & $\begin{array}{c}\text { Relative difference of measured and } \\
\text { calculated value/względna różnica } \\
\text { wielkości zmierzonej } i \text { obliczonej }\end{array}$ \\
\hline $\begin{array}{l}\text { Quantity scraped to piston underside/ilość zgar- } \\
\text { niana do przestrzeni pod tłokiem }\end{array}$ & 8 & 7.252 & $9.35 \%$ \\
\hline $\begin{array}{l}\text { Quantity scraped to crankcase/ilość zgarniana do } \\
\text { skrzyni korbowej }\end{array}$ & 12000 & 11020 & $8.17 \%$ \\
\hline
\end{tabular}

\section{Calculation results concerning piston ring pack operation}

For the analysis of the ring pack operation, a ring pack consisting of a single one-lip sealing (compression) ring, single one-lip scraping ring and a single two-lip scraping ring typically used in spark ignition engines of middle class automobiles has been selected.

The surface geometry of the piston ring package (vertical dimensions are 1000 times greater than horizontal ones) is depicted in Fig. 7.

In the following figures variations of some physical parameters as functions of the crankshaft rotation angle, beginning from the piston bottom dead centre (BDC) of the four-stroke engine operation $\left(0^{\circ}\right)$ are shown. In this case the end of compression phase is at $180^{\circ}$ of crank angle (piston top dead centre - TDC).

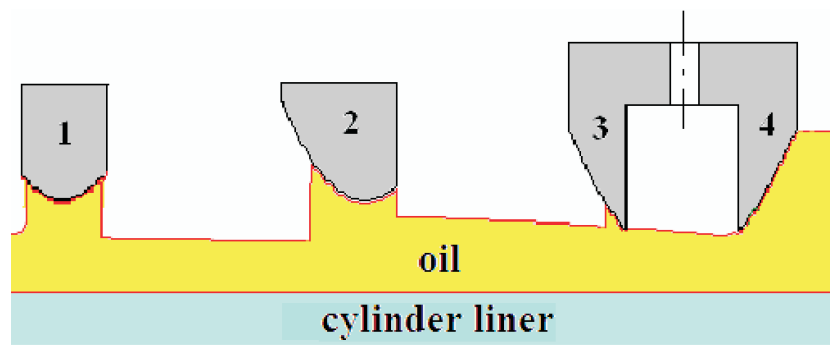

Fig. 7. Ring pack geometry under consideration

Rys. 7. Geometria analizowanego pakietu pierścieni tłokowych

A linear temperature distribution of the cylinder wall from 120 to $200^{\circ} \mathrm{C}$ has been assumed. The temperature variation results in differences in local oil viscosity values.

In Figure 8 gas pressure variations in a piston ring pack as a function of crank angle are shown. The numerical calculation is done on the basis of known cylinder pressure variation and gas leakage through the labyrinth sealing of the piston ring pack (orifices corresponding ring end gaps and ring-side crevices). One can notice the existence of phases of a relatively high pressure load on the upper (compression) ring.
Jedną z wielu wielkości wejściowych programu symulacyjnego była szybkość osiadania mgły olejowej na swobodnej powierzchni tłoczyska. Wielkość tę dobrano w ten sposób, aby uzyskać zadowalającą zgodność zmierzonych i obliczonych objętości zgarnianego oleju w dół do skrzyni korbowej. W tabeli 4 przedstawiono porównanie wielkości zmierzonych i obliczonych oraz procentowy rozrzut wyników.

\section{Wyniki obliczeń dotyczących funkcjonowania pakietu pierścieni tlokowych}

Do analizy funkcjonowania pakietu pierścieni wybrano pakiet pierścieni składający się z jednowargowego pierścienia uszczelniającego, jednowargowego pierścienia zgarniającego i dwuwargowego pierścienia zgarniającego typowy pakiet dla silnika o zapłonie iskrowym samochodu klasy średniej.

Geometria powierzchni (ślizgowych) pakietu pierścieni tłokowych (wymiary pionowe powiększono 1000 razy w stosunku do poziomych) przedstawiona jest na rys. 7 .

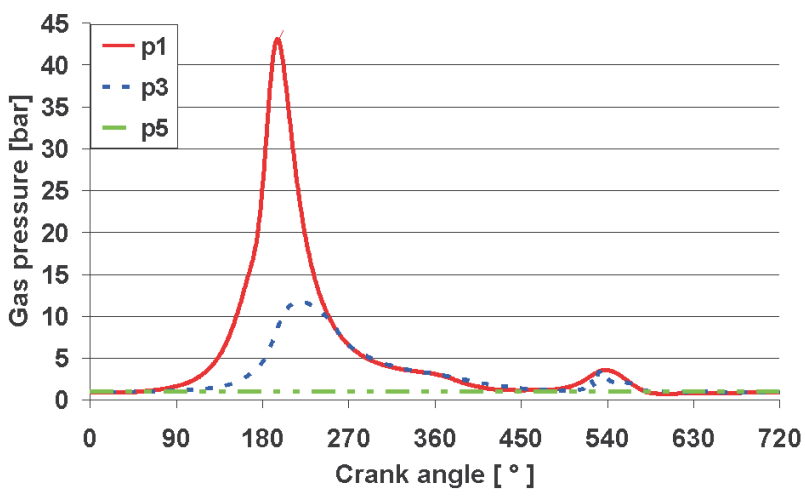

Fig. 8. Gas pressure variations $p_{i}$ versus crank angle: $p_{1}$ - in combustion chamber, $\mathrm{p}_{3}$ - among the $1^{\text {st }}$ and $2^{\text {nd }}$ piston ring, $\mathrm{p}_{5}$ - in crankcase

Rys. 8. Przebiegi zmienności ciśnień gazu $p_{i} w$ funkcji kąta obrotu watu korbowego: $p_{1}-w$ cylindrze, $p_{3}-$ między pierścieniami 1 i 2 , $p_{5}-w$ skrzyni korbowej 
In Figure 9 ring axial lifts in piston grooves as a function of crank angle for analysed engine are shown. Due to big changes of piston acceleration the axial movements of the $1^{\text {st }}$ and $3^{\text {rd }}$ (Fig. 1) piston rings within their grooves can be observed. This phenomenon takes place twice during the whole cycle $\left(0^{\circ}-720^{\circ}\right)$ of the four-stroke engine. The 2nd piston ring (Fig. 1) is strongly pressed by the gas force against the lower flank of piston groove and does not move during the compression and expansion strokes. But then during the exhaust and suction strokes the mentioned gas force is less important and two lifts of the $2^{\text {nd }}$ piston ring within its groove can be observed. Gas pressure variations near the crank angle of $540^{\circ}$ are followed by oscillations of axial movement of the $1^{\text {st }}$ and $2^{\text {nd }}$ piston ring.

The nominal axial clearance of the first and second ring in piston grooves equals $0.20 \mathrm{~mm}$ and for the third piston ring $-0,25 \mathrm{~mm}$. After each short lasting ring movement in a piston groove follows a change of the acting point of the reaction force $R_{x}$ to the other shelf of piston groove and also a sign change of this force (Fig. 3). However during the ring movement between both piston groove shelves, the force $\mathrm{R}_{\mathrm{x}}=0$.

Rapid ring lifts are accompanied by short lasting, but big changes of gas flow areas between rings and piston grooves. They are much bigger than flow areas of ring end gaps, because the opening ranges include the whole piston circumference. In this case temporary rapid changes of gas blowby should be expected.

The hydrodynamic force acts in the radial direction on the ring, which must be compensated by the spring, gas pressure and friction forces in the cylinder groove. The inertia force in the radial direction has been neglected due to very small values of the radial ring velocity. In Fig. 10 the hydrodynamic force for each piston ring necessary for compensating both the gas pressure and radial forces resulting from the ring stiffness is presented. The variations of hydrodynamic forces look similar to variations of inter-ring gas pressures (Fig. 8). In some working phases, the radial gas force $\mathrm{F}_{\text {gas }}$ (Fig. 3) acting to increase the ring diameter is many times greater than the natural force of the ring stiffness $\mathrm{F}_{\mathrm{spr}}$ in the same direction (for example: $\mathrm{F}_{\mathrm{spr}}=375 \mathrm{~N} / \mathrm{m}$ for the compression ring).

Additionally, in the mixed lubrication cases the elastic radial contact forces are expected. In Figure 11 variations in radial components of elastic contact forces are visible. These forces occur in the case of a high gas pressure and low oil viscosity caused by high temperature near the top dead centre. It should be noticed that the values of elastic contact forces are much lower than hydrodynamic forces acting on rings (compare Figs. 10 and 11).

Analysing the calculation results it can be concluded that hydrodynamic forces are generated by relatively low pressure acting on a big surface in contrary to high pressure elastic contacts concentrated on a very small elastic contact area. Due to that the elastic contact seems to be responsible for the wear process.
$\mathrm{Na}$ zaprezentowanych dalej wykresach przedstawiono przebiegi zmian wybranych parametrów fizycznych w funkcji kąta obrotu wału korbowego, rozpoczynając od dolnego martwego położenia (DMP) cyklu pracy silnika czterosuwowego. W tym przypadku koniec suwu sprężania odpowiada $180^{\circ}$ obrotu wału korbowego (górne martwe położenie tłoka - GMP).

Założono liniowy rozkład temperatury na tulei cylindrowej od 120 do $200^{\circ} \mathrm{C}$. Zmiany temperatury wywołują lokalne różnice lepkości oleju.

Na rysunku 8 pokazano zmiany ciśnienia gazu w obrębie pakietu pierścieni tłokowych w funkcji kąta obrotu wału korbowego. Obliczenia numeryczne przeprowadzono w oparciu o znany przebieg zmian ciśnienia gazu w cylindrze i przedmuchów gazu przez uszczelnienie labiryntowe pakietu pierścieni tłokowych (szczeliny przepływowe zamków pierścieni oraz między pierścieniami i rowkami tłoka). Można zauważyć przedziały (kąta obrotu wału korbowego) o stosunkowo wysokim ciśnieniu obciążającym górny pierścień uszczelniający.

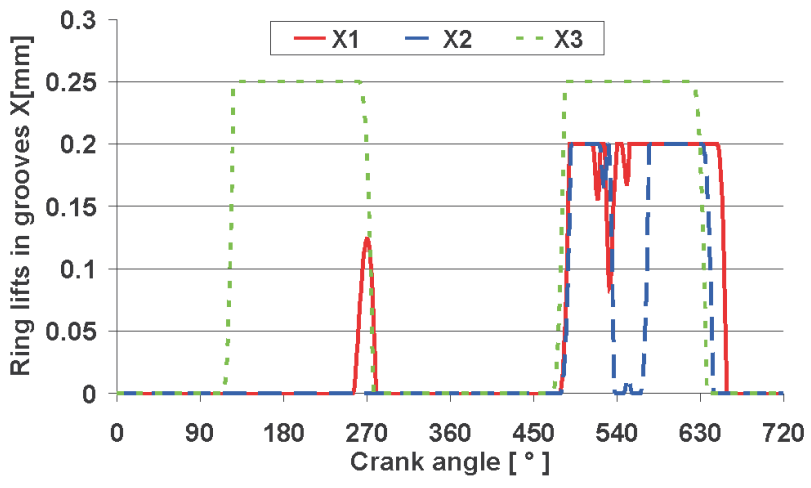

Fig. 9. Variation of ring lift $\mathrm{X}_{\mathrm{i}}$ in piston groove for each piston ring (i - ring number) versus crank angle

Rys. 9. Zmienność osiowych przemieszczeń Xierścieni w rowkach tłoka $w$ funkcji kąta obrotu wału korbowego ( $i$-numer pierścienia)

Na rysunku 9 przedstawiono osiowe wzniosy pierścieni względem rowków tłoka w funkcji kąta obrotu wału korbowego dla analizowanego silnika. Z uwagi na znaczne zmiany przyspieszeń tłoka obserwuje się przemieszczenia osiowe 1. i 3. pierścienia (rys. 1) w obrębie rowków tłoka. To zjawisko występuje dwa razy na cykl pracy $\left(0^{\circ}-720^{\circ}\right)$ silnika czterosuwowego. Natomiast drugi pierścień tłokowy (rys. 1) jest pod wpływem siły gazowej na tyle mocno dociskany do dolnej półki rowka w suwach sprężania i rozprężania, że nie może się od niej wówczas oderwać. Jednakże w następujących potem suwach wydechu i ssania wspomniana siła gazowa staje się mniej znacząca i obserwuje się dwa wzniosy 2. pierścienia $\mathrm{w}$ rowku tłoka. Wahania ciśnienia gazu $\mathrm{w}$ okolicy $540^{\circ}$ skutkują wahaniami osiowych przemieszczeń 1. i 2. pierścienia. Nominalne osiowe luzy 1. i 2. pierścienia w rowkach tłoka wynoszą 0,2 mm, a dla 3. pierścienia tłokowego - 0,25 mm. Każdy z natury krótkotrwały przeskok pierścienia spowoduje przesunięcie punktu działania 


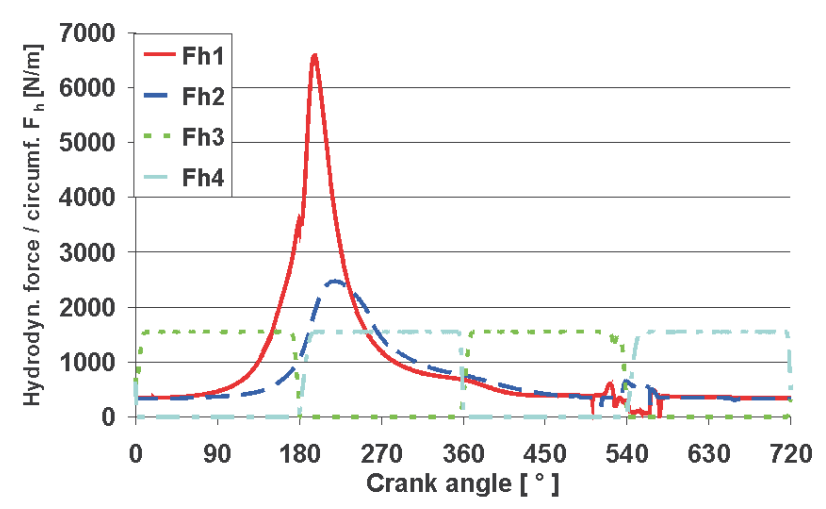

Fig. 10. Variation of hydrodynamic force Fh_i for each piston ring versus crank angle ( $\mathrm{i}$ - lip number of piston ring pack - Fig. 7)

Rys. 10. Zmienność sil hydrodynamicznych Fh_i pierścieni tłokowych w funkcji kąta obrotu watu korbowego (i-numer wargi pakietu pierścieni -rys. 7)

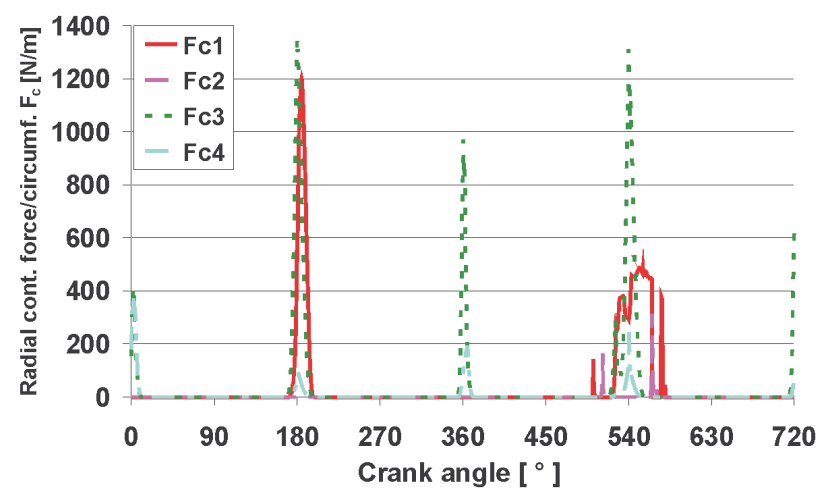

Fig. 11. Variation of radial component of contact force $F_{c i}$ for each piston ring versus crank angle ( $\mathrm{i}$ - lip number of piston ring pack - Fig. 7)

Rys. 11. Zmienność promieniowych sit kontaktu $F_{c i}$ pierścieni tłokowych $w$ funkcji kata obrotu watu korbowego (i-numer wargi pakietu pierścieni-rys. 7)

The hydrodynamic friction forces as functions of the crankshaft rotation were calculated and presented in Fig. 12. These forces significantly depend on piston velocity. For this reason the highest values of hydrodynamic friction forces should be noticed at crank angles, where the maximum piston velocity is reached. These forces could be neglected in the piston motion phases corresponding to low velocity near the reverse points.

Near the top dead centre (at high oil temperature) the additional tangential components of elastic contact forces (friction forces) should be noticed (Fig. 13). The sign change of these forces at TDC results from the sign change of piston velocity.

The oil film thickness was calculated from the pressure distribution in the gap between the ring land and cylinder liner. In addition the temperature variation along the cylinder liner results in differences in local oil viscosity values. In order to take this effect into account, the assumed linear temperature distribution along the liner was applied for numerical calculation of hydrodynamic lubrication of piston ring pack. siły reakcji $\mathrm{R}_{\mathrm{x}}$ do przeciwległej półki rowka tłoka i zmianę znaku tej siły (rys. 3). Jednakże w czasie samego przeskoku pomiędzy dwoma półkami rowka tłoka, siła $\mathrm{R}_{\mathrm{x}}=0$.

Przeskokom pierścieni towarzyszą krótkotrwałe, ale duże zmiany przekrojów przepływu gazu między pierścieniami a półkami rowków tłoka. Są one znacznie większe od przekrojów przepływu przez zamki pierścieni, gdyż oznaczają otwarcie szczelin na całym obwodzie pierścienia. W tym przypadku oczekiwać należy krótkotrwałych, gwałtownych zmian przedmuchu gazu.

Siła hydrodynamiczna działa w kierunku promieniowym na pierścień tłokowy i musi być skompensowana przez siłę sprężystości, ciśnienia gazu i tarcia w rowku tłoka. Zaniedbano siłę bezwładności w kierunku promieniowym z uwagi na bardzo małe wartości promieniowej prędkości pierścienia. Na rysunku 10 zobrazowano siły hydrodynamiczne dla każdego pierścienia tłokowego potrzebne do skompensowania sił wynikających z ciśnień gazu i ze sprężystości pierścieni. Zmienność sił hydrodynamicznych wygląda podobnie, jak zmienności ciśnień gazu między pierścieniami (rys. 8). W pewnych fazach pracy silnika promieniowa siła gazowa $\mathrm{F}_{\text {gas }}$ (rys. 3), powodująca zwiększanie średnicy pierścienia, jest wielokrotnie większa od naturalnej siły sprężystości pierścienia Fspr działającej w tym samym kierunku (np.: $\mathrm{F}_{\mathrm{spr}}=375 \mathrm{~N} / \mathrm{m}$ dla pierścienia uszczelniającego).

W przypadku tarcia mieszanego można spodziewać się dodatkowo występowania promieniowych sił sprężystego kontaktu (z chropowatościami powierzchni). Na rysunku 11 widoczne są przebiegi zmian składowych promieniowych sił kontaktu. Siły te pojawiają się w przypadku wysokich ciśnień gazu i niskiej lepkości oleju spowodowanej przez wysoką temperaturę w okolicach górnego martwego punktu tłoka. Należy odnotować, że wartości sił sprężystego kontaktu są znacznie mniejsze od sił hydrodynamicznych działających na pierścienie (por. rys. $10 \mathrm{i} 11$ ).

Analizując wyniki obliczeń, można wnioskować, że siły hydrodynamiczne powstają przy względnie niskich ciśnieniach działających na dużej powierzchni, w przeciwieństwie do wysokich ciśnień sprężystego kontaktu skoncentrowanego na bardzo małej powierzchni styku. Wydaje się, że z tego powodu zjawiska sprężystego kontaktu są odpowiedzialne za proces zużycia.

Obliczone przebiegi sił tarcia hydrodynamicznego w funkcji kąta obrotu wału korbowego zaprezentowano na rys. 12. Siły te w znaczący sposób zależą od prędkości tłoka. Z tego względu największe wartości hydrodynamicznych sił tarcia są widoczne dla kątów obrotu wału korbowego, gdzie osiągana jest maksymalna prędkość tłoka. Siły te mogą być pominięte w fazach ruchu tłoka odpowiadających niskiej prędkości blisko punktów zwrotnych.

Blisko górnego zwrotnego punktu tłoka (gdzie panuje wysoka temperatura oleju) widoczne są dodatkowo składowe styczne sił sprężystego kontaktu (siły tarcia) (rys. 13). Zmiana znaku tych sił w górnym martwym położeniu (GMP) tłoka wynika ze zmiany znaku prędkości tłoka.

Grubość filmu olejowego obliczono na podstawie rozkładu ciśnienia w szczelinie między wargą pierścienia i tuleją 


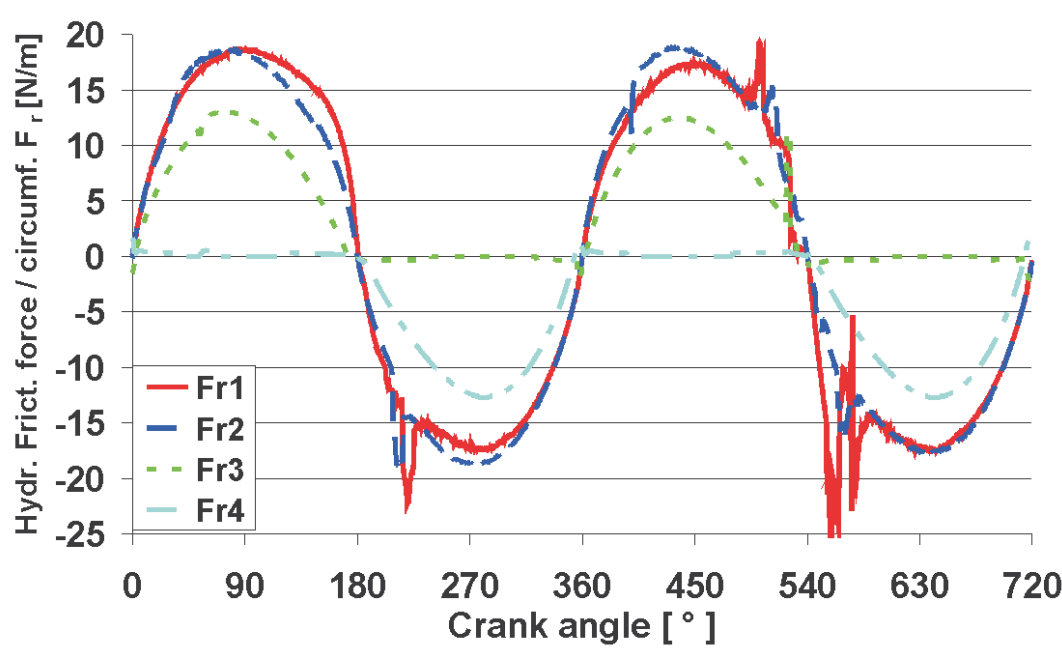

Fig. 12. Variation of hydrodynamic friction force $\mathrm{F}_{\mathrm{r} i \mathrm{i}}$ for each piston ring versus crank angle (i - lip number of piston ring pack - Fig. 7)

Rys. 12. Zmienność sił tarcia płynnego $F_{\text {hi }}$ pierścieni tłokowych w funkcji kąta obrotu wału korbowego ( $i$-numer wargi pakietu pierścieni-rys. 7)

The motion of the ring pack scraping and distributing oil on the cylinder liner leaves the oil film profile shown in Fig. 14 after a few cycles of operation. An uneven oil film distribution along the cylinder liner can be clearly seen. Low film thickness near the piston top dead centre (TDC) and peaks of accumulated oil near the leading ring lips should be noticed. The minimum oil film thickness at TDC is about $0.2-0.3 \mu \mathrm{m}$ and can be compared with RMS roughness of the cylinder liner that equals $0.22 \mu \mathrm{m}$. The very low local film thickness values near TDC can be explained by the existence of high gas pressure and temperature values existing in this area during the compression and working phases of engine operation. Due to high gas forces piston rings are strongly pressed against the cylinder surface. On the other hand, high temperature reduces the oil viscosity.

Variation of the twist angle for each ring is shown in Fig. 15. Maximal values of the twist angle appear in the phases of piston motion corresponding to high gas pressure in the combustion chamber and reach the following values: $-6.8^{\prime}$ (minutes) for the $1^{\text {st }}$ (top) ring, $-2.6^{\prime}$ for the $2^{\text {nd }}$ ring and $-0.9^{\prime}$ for the $3^{\text {rd }}$ ring.

Variation of the twist angle of the scraper ring is different from that in the compression ring. The twist angle of the compression ring changes its sign, while the scraper ring has mainly the same sign of the twist angle (Fig. 3). It should be observed that different twist angles of the considered rings result from different shapes of the scraper and compression ring lips (Fig. 7). cylindrową. Ponadto zmienność temperatury wzdłuż tulei cylindrowej powoduje różnice lokalnych wartości lepkości oleju. W celu uwzględnienia tego zjawiska, w obliczeniach numerycznych hydrodynamicznego smarowania pakietu pierścieni tłokowych założono liniowy rozkład temperatury wzdłuż tulei cylindrowej.

Ruch pakietu pierścieni zgarniających i rozprowadzających olej na tulei cylindrowej pozostawia po kilku cyklach pracy (silnika) profil filmu olejowego pokazany na rys. 14. Dobrze widoczny jest nierównomierny rozkład filmu olejowego wzdłuż gładzi cylindrowej. Zauważyć można małą grubość warstwy (oleju) blisko górnego martwego punktu (GMP) oraz lokalne wzrosty grubości zakumulowanego oleju przy przednich wargach pierścieni.

Minimalna grubość filmu olejowego w GMP tłoka wynosi około $0,2-0,3 \mu \mathrm{m}$ i może być porównana ze średnim odchyleniem kwadratowym (RMS) chropowatości gładzi cylindrowej równym $0,22 \mu \mathrm{m}$. Tak mała grubość filmu olejowego może być ponadto wyjaśniona istnieniem w tym obszarze bardzo dużych ciśnień i temperatur gazu występujących podczas suwu sprężania i rozprężania w cyklu pracy silnika. Wskutek wysokich ciśnień gazu pierścienie tłokowe są mocno dociskane do powierzchni cylindra, natomiast wysoka temperatura obniża lepkość oleju.

Przebiegi zmian kątowych odkształceń poszczególnych pierścieni pokazano na rys. 15. Maksymalne wartości odkształceń kątowych pojawiają się w zakresie kątów obrotu wału korbowego odpowiadających wysokim ciśnieniom gazu w cylindrze i osiągają wartości: -6,8' (minut) dla pierwszego (górnego) pierścienia, -2,6’ dla drugiego pierścienia i $-0,9^{\prime}$ dla trzeciego pierścienia.

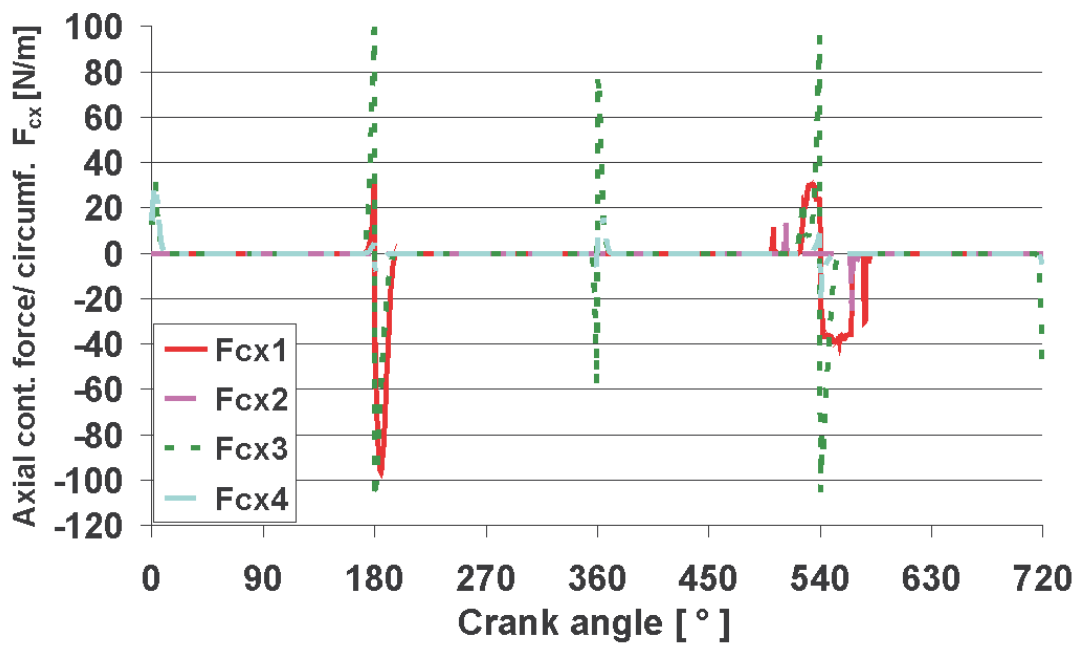

Fig. 13. Variation of tangential component of contact force $\mathrm{F}_{\mathrm{cx} \text { i }}$ for each piston ring versus crank angle (i - lip number of piston ring pack - Fig. 7)

Rys. 13. Zmienność osiowych sit kontaktu $F_{c x i}$ pierścieni tłokowych w funkcji kąta obrotu wału korbowego ( $i$-numer wargi pakietu pierścieni - rys. 7) 


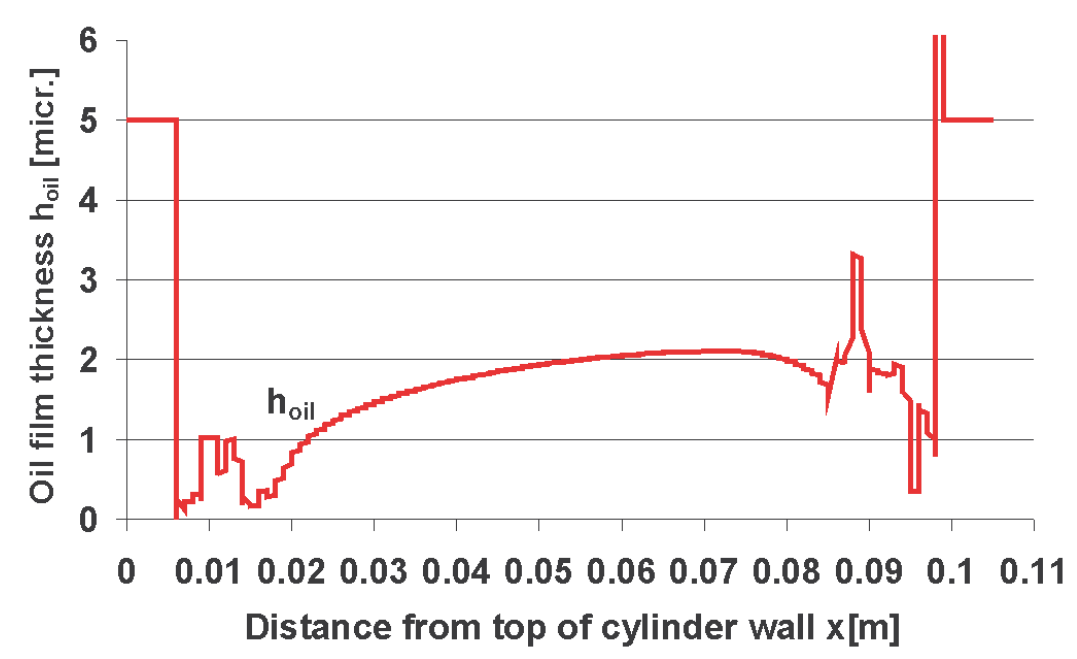

Fig. 14. Variation of the oil film thickness $\mathrm{h}_{\mathrm{oil}}$ left by the ring pack along cylinder wall and mean value of the oil film thickness $h_{\text {mea }}$

Rys. 14. Rozkład grubości filmu olejowego $h_{\text {oil }}$ na gładzi cylindrowej oraz średnia grubość warstewki oleju $h_{\text {mean }}$

The twist angle varies between $-0.9^{\prime}$ and $0.9^{\prime}$ for the twin-land oil control ring. Gas forces practically do not influence the oil ring motion. An elastically deformed two lip ring scrapes oil mainly by the consequent lip. The succeeding lip is located deeper in the oil film, scraping oil to the gap between lips. The accumulated oil flows out through the special gaps made in the ring.

\section{Conclusions}

1. The worked out mathematical model and simulation programme give a lot of practical information that would be more complicated and expensive to obtain using only experimental methods.

2.In order to use the simulation programme a number of important input data (also experimental data) is needed. This mainly concerns the system pistonring-cylinder, for example geometrical profiles of sliding surfaces of piston rings, thermal deformations of piston

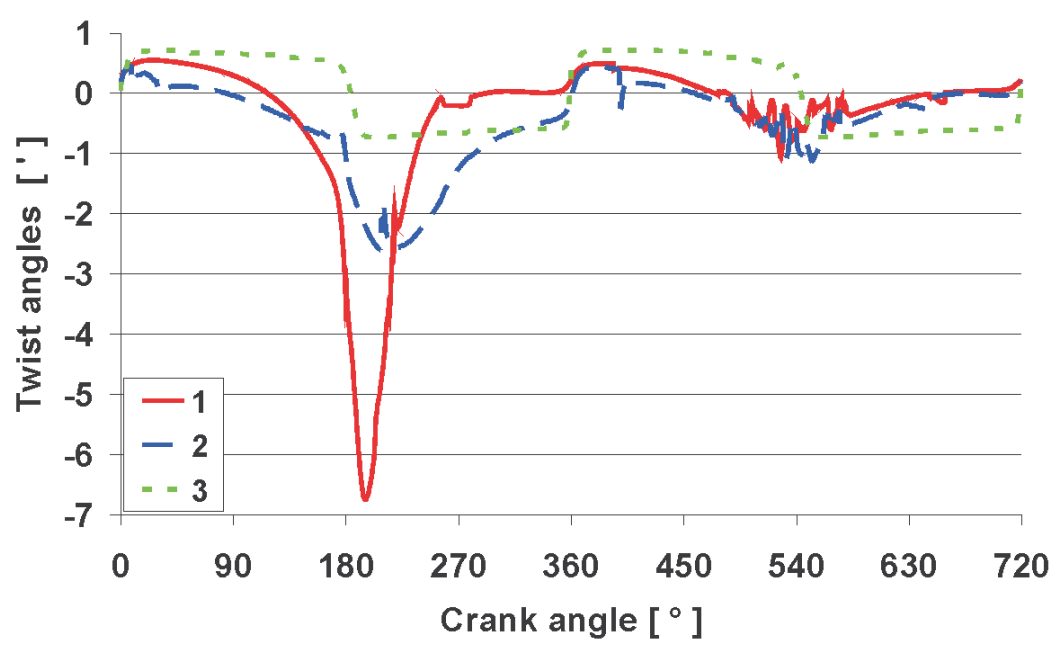

Fig. 15. Variation of twist angle Theta for each piston ring ( $\mathrm{i}$ - ring number) versus crank angle Rys. 15. Zmienność kątowych odkształceń Theta ${ }_{i}$ pierścieni tłokowych ( $i$-numer pierścienia) w funkcji kata obrotu watu korbowego
Przebieg zmienności odkształcenia kątowego 2. pierścienia (uszczelniającozgarniającego) różni się od analogicznego przebiegu dla 1. pierścienia (uszczelniającego). Odkształcenie kątowe pierścienia uszczelniającego zmienia znak, podczas gdy odkształcenie kątowe pierścienia uszczelniająco-zgarniającego ma przeważnie ten sam znak (rys. 3). Należy zauważyć, że różnice przebiegów odkształceń kątowych wspomnianych pierścieni wynikają z różnych kształtów warg pierścieni uszczelniającozgarniającego i uszczelniającego (rys. 7).

Odkształcenie kątowe dwuwargowego pierścienia zgarniającego zmienia się od $-0,9^{\prime}$ do $0,9^{\prime}$. Siły gazowe nie wpływają na ruch pierścienia zgarniającego. Odkształcony sprężyście dwuwargowy pierścień olejowy zgarnia olej głównie swoją przednią wargą. Tylna warga znajduje się głębiej w oleju, zgarniając olej do przestrzeni między wargami. Zakumulowany olej wypływa wtedy przez specjalne kanaliki odpływowe tego pierścienia. and cylinder, profiles of piston grooves, experimental measurements of gas pressure among the rings etc.

3. The model and simulation programme have been experimentally verified for two marine engines (during working periods at the engine designing centre Wärtsilä in Switzerland).

4. The simulation model characterizes well the piston ring pack operation of different kinds of internal combustion engines (two- and four-stroke). It concerns mainly variations of gas pressure among the rings as functions of crank angle and exhaust gas flow rates (blow-by) through the labyrinth seal of a piston ring pack.

\section{Wnioski}

1. Opracowany model matematyczny i program symulacyjny dostarczają dużo informacji, których uzyskanie metodami eksperymentalnymi byłoby bardzo skomplikowane i kosztowne. 2. Użycie programu wymaga jednak wielu istotnych danych (w tym eksperymentalnych). Dotyczy to głównie układu tłok-pierścienie-cylinder, np. geometrycznych profili powierzchni ślizgowych pierścieni tłokowych, odkształceń termicznych tłoka i cylindra, profili rowków tłoka, pomiarów ciśnień gazu między pierścieniami itd.

3. Model i program symulacyjny zweryfikowano eksperymentalnie dla dwu silników okrętowych (podczas pracy w 
5. Analyzing scraped oil volumes by the ring pack (of the gland-box of marine internal combustion engine), a satisfactory quantitative compatibility of results concerning numerical calculations and experimental investigations can be noticed.

6. Due to high temperatures the oil viscosity is very low and consequently the oil film thickness is very thin along the cylinder liner. In this case is important to use a model of mixed lubrication and to take the surface roughness into account.

7. The calculation results prove that the twist movement of piston rings should be taken into account if the lubrication problem of cylinder liner is analysed.

8. The main aims of simulation of the ring motion is to predict lubrication conditions, define areas of the possible cylinder liner wear, changes of the piston ring surface shape deformation resulting from wear, and finally to define the gas leakage through the sealing ring set. Further investigation of these phenomena is strongly recommended.

Artykut recenzowany ośrodku konstrukcyjnym silników Wärtsilä w Szwajcarii).

4. Model symulacyjny dobrze odzwierciedla funkcjonowanie pakietu pierścieni tłokowych różnych rodzajów silników spalinowych (dwu- i czterosuwowych). Dotyczy to głównie przebiegów ciśnień gazu między pierścieniami w funkcji kąta obrotu wału korbowego oraz natężeń przedmuchów spalin przez uszczelnienie labiryntowe pakietu pierścieni.

5. Analizując zgarniane objętości oleju przez pakiet pierścieni (dławnicy okrętowego silnika spalinowego), można zauważyć dobrą zgodność ilościową wyników obliczeń numerycznych i badań eksperymentalnych.

6.Z uwagi na wysokie temperatury oleju jego lepkość jest bardzo niska, co w konsekwencji prowadzi do bardzo małych grubości filmu olejowego na gładzi cylindrowej. W tym przypadku istotne jest zastosowanie modelu tarcia mieszanego oraz uwzględnienie chropowatości powierzchni.

7. Wyniki badań symulacyjnych wskazują na potrzebę uwzględniania odkształceń kątowych pierścieni przy analizach smarowania gładzi cylindrowej.

8. Głównym celem symulacji ruchu pierścieni jest przewidywanie warunków smarowania, wyznaczenie obszarów potencjalnego zużycia gładzi cylindrowej, zmian profilu powierzchni pierścieni wynikających ze zużycia, a w rezultacie wyznaczenie przedmuchu gazu przez pakiet pierścieni uszczelniających. Wskazane jest dalsze badanie tych zjawisk.

\section{Bibliography/Literatura}

[1] Bobrowski D.: Probabilistyka w zastosowaniach technicznych. WNT, Warszawa 1980.

[2] Demmerle R., Barrow S., Terrettaz F., Jaquet D.: New Insights into the Piston Running Behaviour of "Sulzer" Large Bore Diesel Engines, CIMAC Congress, Hamburg May 2001.

[3] Greenwood J., Tripp J.H.: The contact of Two Nominally Flat Rough Surfaces. Proc I. Mech. E., Vol. 185, 1971, pp. 625-633.

[4] Iskra A.: Parametry filmu olejowego w węzłach mechanizmu tłokowo-korbowego silnika spalinowego. Wydawnictwo Politechniki Poznańskiej, Poznań 2001.

[5] Koszałka G.: Modelling the blowby in internal combustion engine. Part 1: A mathematical model, The Archive of Mechanical Engineering, Vol. LI, Number 2, 2004, pp. 245-257; Part 2: Primary calculations and Verification of the model, The Archive of Mechanical Engineering, Vol. LI, No. 4, 2004.

[6] Patir N., Cheng H.S.: An Average Flow Model for Determining Effects of Three-Dimensional Roughness on Partial Hydrodynamic Lubrication. Transactions of ASME, Vol 100, January 1978.

[7] Patir N., Cheng H.S.: Application of Average Flow Model to Lubrication Between Rough Sliding Surfaces. Transactions of ASME, Vol 101, April 1979.

[8] Räss K., Amoser M.: Progressive development of two-stroke engine tribology. Paper No. 83, CIMAC Congress, Vienna 2007.

[9] Serdecki W.: Badania współpracy elementów układu tłokowo-cylindrowego silnika spalinowego. Wydawnictwo Politechniki Poznańskiej, Poznań 2002.

[10] Tian T., Nordzij L.B., Wong V.W., Heywood J.B.: Modeling Piston-Ring Dynamics, Blowby, and Ring-Twist Effects.
Transactions of ASME, Journal of Engineering for Gas Turbines and Power, Vol. 120, October 1998, pp. 843-854.

[11] WolffA., Piechna J.: Numerical simulation of piston ring pack operation. The Archive of Mechanical Engineering, Vol. L, No. 3, 2003,pp. 303-329.

[12] Wolff A., Piechna J.: Numerical simulation of piston ring pack operation in the case of mixed lubrication. The Archive of Mechanical Engineering, Vol. LII, No. 3, 2005, pp. 157-190.

[13] Wolff A.: Badania symulacyjne przepływu gazu przez uszczelnienie labiryntowe pierścieni tłokowych. Zeszyty Naukowe Instytutu Pojazdów, Wydział Samochodów i Maszyn Roboczych, Politechnika Warszawska, zeszyt 2, Warszawa 2007.

[14] Wolff A., Piechna J.: Numerical simulation of piston ring pack operation with regard to ring twist effects. The Archive of Mechanical Engineering, Vol. LIV, No. 1, pp. 65-99, Warsaw 2007.

[15] Wolff A.: Symulacja cyfrowa działania pakietu pierścieni tłokowych. Polska Akademia Nauk Oddział w Krakowie, Teka Komisji Motoryzacji pt. Konstrukcja, badania, eksploatacja, technologia pojazdów samochodowych i silników spalinowych, zeszyt nr 33-34, Kraków 2008, ss. 467-474.

Mr. Andrzej Wolff, DEng. - doctor in the Faculty of Transport at Warsaw University of Technology.

Dr inż. Andrzej Wolff-adiunkt na Wydziale Transportu Politechniki Warszawskiej.

e-mail:wolff@it.pw.edu.pl 